\title{
Association of glutathione S-transferase (GSTM1 and GSTT1) genes with chronic myeloid leukemia
}

\author{
Yaya Kassogue ${ }^{1}$, Hind Dehbi ${ }^{1}$, Meryem Quachouh², Asma Quessar ${ }^{2}$, Said Benchekroun² and Sellama Nadifi ${ }^{*}$
}

\begin{abstract}
Chronic myeloid leukemia (CML), as most of cancers results from a complex interaction between genetic or non genetic factors. Exposures to xenobiotics endogenous or exogenous associated with a reduced individual ability in detoxifying activity, constitutes a risk of developing cancer. It is known that polymorphism of glutathione S-transferases (GSTs) genes affects the detoxification of xenobiotics. Thus, we conducted a case-control study in which 92 patients (Mean age \pm SD, $40.62 \pm 12.7$ years) with CML and 93 healthy unrelated controls (Mean age \pm SD, $41.38 \pm 13.4$ years) have participated. GSTM1 and GSTT1 genotypes were determined by multiplex polymerase chain reaction. Logistic regression was used to assess the possible link between GSTM1 and GSTT1 null genotypes and CML as well as between combined genotypes and CML. GSTM1 null genotype frequency was slightly higher in patients than control (48.9\% vs. 40.9\%) but, it was not associated with CML (OR 95\% Cl, 1.4, 0.78-2.48; $\mathrm{p}=0.271)$. Moreover, GSTT1 null genotype frequency showed a similar trend between patients and control (17.4\% vs. 9.7\%; OR 95\% Cl, 1.97, 0.82-4.71; $\mathrm{p}=0.13)$. Surprisingly, GSTT1 null genotype was significantly associated with the risk of CML in males (OR 95\% Cl, 5, 1.25-20.1; $p=0.023$ ). The combined GSTM1 present/GSTT1 null genotype was found to have a limited effect against the risk of CML (OR 95\% Cl, 0.3, 0.08-0.99; $p=0.049)$. Our findings have shown that GSTT1 null genotype might be a risk factor of CML in males. While, GSTT1 present genotype might be considered as protective against CML. However, further studies with a large sample size are needed to confirm our findings.
\end{abstract}

Keywords: Glutathione S-transferases; GSTM1; GSTT1; CML

\section{Introduction}

Chronic myeloid leukemia (CML) is a blood cancer secondary to the presence of the reciprocal translocation $\mathrm{t}(9 ; 22)(\mathrm{q} 34 ; \mathrm{q} 11)$ or BCR-ABL gene fusion causing a malignant proliferation of hematopoietic cells (Deininger et al. 2000). However, The etiology of CML like most of cancers, results from a complex interaction between several factors, among others exposure to ionizing and non ionizing radiation, carcinogens present in the environment such as benzene, smoke and pesticides (Salagovic et al. 2000; Gervasini et al. 2007). These factors considered as genotoxics may affect the biotransformation of xenobiotics and cause damage to the DNA of hematopoietic cells and foster the occurrence of CML (Belitsky \& Yakubovskaya 2008). Obviously, depending to the genetic constitution on the individual level, the body prevents

\footnotetext{
* Correspondence: nadifi@labgenmed.com

${ }^{1}$ Genetics and Molecular Pathology Laboratory, Medical School of Casablanca, 19 Rue Tarik Ibnou Ziad, Casablanca BP 9154, Morocco Full list of author information is available at the end of the article
}

such damage, thanks to enzymes which play a major role in the activation/detoxification of carcinogens, repair of DNA damage and programming of mutant cells to apoptosis (Belitsky \& Yakubovskaya 2008; Hayes and Pulford 1995; Fang et al. 2013). It is noteworthy that hereditary differences which affect an individual's ability to metabolize xenobiotics represent significant factors in predisposition to develop cancer such as CML (Taioli 1999; Siraj et al. 2008). Glutathione S-transferases (GSTs) are enzymes of phase II, which participate in cellular detoxification by converting active procarcinogenic metabolites of phase I enzymes (cytochrome P450) into inactive metabolites and soluble glutathione, easily execretable. Nowadays, eight classes of GSTs have been identified, including alpha (GSTA), mu (GSTM) theta (GSTT), pi (GSTP), zeta (GSTZ), sigma (GSTS), kappa (GSTK) and omega (GSTO) (Mannervik et al. 1992). Among these, GSTM1 and GSTT1 genes which have been mapped on chromosome $1 \mathrm{p} 13.3$ and 22q11.2 respectively, are the most studied (Pearson et al. 1993; Webb et al. 1996). It is known that 
deletions in GSTM1 and GSTT1 genes is associated with reduced or absence of enzyme activity (Hallier et al. 1993). Moreover, numerous studies have shown the link between the lack of enzyme activity in GSTM1 and GSTT1 and the susceptibility to develop various types of cancer, such as oral cancer, gastric cancer, bladder cancer, and CML in different ethnical groups worldwide (Bajpai et al. 2007; Sharma et al. 2013; Dunna et al. 2013; Ma et al. 2013; Dong et al. 2013; Bhat et al. 2012). Furthermore, other studies have found an association between GSTM1 and GSTT1 deletions and the response to chemotherapy, such as disease free survival, overall survival or toxicity (Voso et al. 2002; Mossallam et al. 2006). Given the absence of data on the frequencies of GSTM1 and GSTT1 genotypes in our population, we decided to carry out this case-control study with the aim to establish firstly their frequencies in the population and secondly estimate the possible link between the null genotypes and the occurrence of chronic myeloid leukemia in a sample of the Moroccan population.

\section{Materials and methods Subjects}

This study was performed after approval of the local Ethics Committee and individual informed consent from patients and control. A total of 92 patients have participated. Patient's selection was based on the presence of clinically-hematologic signs and Philadelphia chromosome or BCR-ABL gene fusion (Baccarani et al. 2009). Patients were recruited in the department of OncoHematology of the Ibn Rochd University Hospital in Casablanca, Morocco from 2011 to 2013. During the same period 93 unrelated healthy controls without a family history of cancer were recruited at the laboratory of genetic and molecular diseases, Faculty of Medicine, the Hassan II University in Casablanca. Four milliliters of venous blood were collected in EDTA tube and kept to minus $20^{\circ} \mathrm{C}$ till DNA extraction.

\section{Genotyping of GSTM1 and GSTT1 polymorphism}

Salting-out method was used to extract DNA from white blood cells (Miller et al. 1988). GSTM1 and GSTT1 polymorphism were detected by using a multiplex polymerase chain reaction (PCR) in which BCL2 gene as an internal control was used. The PCR was carried out in a mixture containing $100 \mathrm{ng}$ of genomic DNA, 1X of 5X GoTaq Flexi Buffer (Promega), $1.5 \mathrm{mM}$ of $\mathrm{MgCl} 2$, $0.2 \mathrm{mM}$ of each dNTP, $10 \mathrm{pM}$ of each primer and $0.5 \mathrm{U}$ of GoTaq polymerase (Promega) completed to $25 \mu \mathrm{l}$ with molecular grade water. Forward and reverse primers were 5'-TTCCTTACTGGTCCTCACATCTC-3' and 5'-T CACCGGATCATGGCCAGCA-3' respectively, for GSTT1; 5'-GAACTCCCTGAAAAGCTAAAGC-3' and 5'- GTTGG GCTCAAATATACGGTGG-3', respectively for GSTM1.
Forward and reverse primers for BCL2 gene were 5'-G CAATTCCGCATTTAATTCATGG-3' and 5'- GAAACAG GCCACGTAAAGCAAC-3', respectively (Voso et al. 2002). PCR amplification was performed with an initial denaturation at $94^{\circ} \mathrm{C}$ for 5 minutes, followed by 35 cycles at $94^{\circ} \mathrm{C}$ for 1 minute, $61^{\circ} \mathrm{C}$ for 1 minute, $72^{\circ} \mathrm{C}$ for 1 minute and a last extension at $72^{\circ} \mathrm{C}$ for 7 minutes. PCR products were analyzed on a $2 \%$ agarose gel stained with $0.5 \mu \mathrm{g} / \mathrm{mL}$ ethidium bromide. The GSTT1, GSTM1 and BCL2 produce $480 \mathrm{bp}, 219 \mathrm{bp}$ and $154 \mathrm{bp}$ respectively. The presence of BCL2 without GSTT1 or GSTM1 reflects their deletion.

\section{Statistical analysis}

Logistic regression was used to assess the risk between GSTT1 and GSTM1 null genotypes and the occurrence of CML. Odds ratio (OR) with a confidence interval (CI) of $95 \%$ was calculated. The chi-square test was used to compare the genotype distribution between patients and control. A p-value less than 0.05 was considered as statistically significant. We have used the statistical package SPSS version 16 (SPSS Inc., Chicago, IL, USA).

\section{Results}

In this case-control study, we explored the frequency of GSTM1 and GSTT1 genotypes in 92 CML patients and 93 controls. The patients were composed of 34 males (37\%), 58 females (63\%) with a mean age of $40.62 \pm 12.7$; range (18-76 years). However, the control was composed of 39 males (41.9\%), 54 females (58.1) with a mean age of $41.38 \pm 13.4 ;$ range (18-77). The frequencies of GSTM1 and GSTT1 genotypes between patients and control are summarized in Table 1 . We found that the GSTM1 null genotype was moderately more frequent in patients (48.9\%) compared to control (40.9\%), however, this difference was not statistically significant (OR 95\% CI, 1.4, 0.78-2.48; $\mathrm{p}=0.271$ ). This observation has remained valid for the GSTT1 null genotype with a frequency of $17.4 \%$ in patients against $9.7 \%$ in the control group (OR 95\% CI, 1.97, 0.82-4.71; p=0.13) (Table 1). The combination of both polymorphisms shows that

\begin{tabular}{|c|c|c|c|c|}
\hline \multirow[t]{2}{*}{ GST polymorphism } & Patients & Control & OR & $P$ value \\
\hline & N (\%) & N (\%) & $95 \% \mathrm{Cl}$ & \\
\hline \multicolumn{5}{|l|}{ GSTM1 } \\
\hline Present & $47(51.1)$ & $55(59.1)$ & 1 & \\
\hline Null & 45 (48.9) & $38(40.9)$ & $1.4(0.78-2.48)$ & 0.271 \\
\hline \multicolumn{5}{|l|}{ GSTT1 } \\
\hline Present & 76 (82.6) & $84(90.3)$ & 1 & \\
\hline Null & $16(17.4)$ & $9(9.7)$ & $1.97(0.82-4.71)$ & 0.13 \\
\hline
\end{tabular}


subjects carrying the GSTM1 present/GSTT1 null were associated with a limited effect (OR 95\% CI, 0.3, 0.08$0.99 ; \mathrm{p}=0.049)$. Other types of combination showed no trend. The dual deletion which corresponds to GSTM1 null and GSTT1 null genotypes has been observed in 6 patients $6.5 \%$ against 5 control $5.4 \%$ Table 2. Surprisingly, the distribution of participants based on gender revealed that the GSTT1 null genotype is associated with the development of CML in males (OR 95\% CI, 5, 1.2520.1; $\mathrm{p}=0.023$ ) (Table 3). However, in females the GSTM1 and GSTT1 null genotypes did not appear to be associated with the occurrence of CML (Table 4).

\section{Discussion}

The development of cancer results from an imbalance between exposure to carcinogens (endogenous and exogenous) and the capacity of various enzyme systems engaged in activation or in the detoxification of xenobiotics (Kawajiri et al. 1993). Interindividual genetic variation in xenobiotics metabolizing enzymes has been associated with cancer development (Taningher et al. 1999). Nowadays, many epidemiological studies have shown the implication of GSTM1 and GSTT1 polymorphism in tumorigenesis such as CML (Fang et al. 2013; Duggan et al. 2013).

In the current study, the GSTM1 null genotype frequency $(40.9 \%)$ was comparable to that observed in Caucasians and Asians (40-62\%) but higher than that observed in African-Americans ((16-36\%). However, the frequency of GSTT1 null genotype (9.7\%) in our population showed a similar trend to that observed in Caucasians (10-26\%) but was less than that observed in Asians (35-52\%) (Garte et al. 2001; Van der Logt et al. 2004). The frequency of the homologous deletion (GSTM1 and GSTT1 null genotypes), synonymous of absence of enzyme activity was less than that observed in Caucasians (5.4\% vs. $10.4 \%)$ and that of the Asian population (5.4\% vs. 24.6\%) (Garte et al. 2001). Trends in variability of GSTM1 and GSTT1 null genotypes within a given population might help to estimate the risk of subjects in the development of certain cancers.

In the current study, we noticed that the GSTM1 null genotype was slightly higher in patients (48.9\%) than in

Table 2 Risk assessment of CML between different combinations of GSTM1 and GSTT1 genotypes

\begin{tabular}{llllll}
\hline GSTM1 & GSTT1 & $\begin{array}{l}\text { Patients } \\
\text { N (\%) }\end{array}$ & $\begin{array}{l}\text { Control } \\
\text { N (\%) }\end{array}$ & $\begin{array}{l}\text { OR } \\
\mathbf{9 5 \% ~ C l ~}\end{array}$ & P value \\
\hline Present & Present & $37(40.2)$ & $51(54.8)$ & 1 & \\
Present & Null & $10(10.9)$ & $4(4.3)$ & $0.3(0.08-0.99)$ & 0.049 \\
Null & Present & $39(42.4)$ & $33(35.5)$ & $0.61(0.33-1.15)$ & 0.128 \\
Null & Null & $6(6.5)$ & $5(5.4)$ & $0.61(0.17-2.13)$ & 0.434 \\
\hline
\end{tabular}

Table 3 Effect of GSTM1 and GSTT1 genotypes on the development of CML in males

\begin{tabular}{lllll}
\hline GST polymorphism & $\begin{array}{l}\text { Patients } \\
\mathbf{N}(\%)\end{array}$ & $\begin{array}{l}\text { Control } \\
\mathbf{N}(\%)\end{array}$ & $\begin{array}{l}\text { OR } \\
\mathbf{9 5 \%} \mathbf{~ C l}\end{array}$ & P value \\
\hline GSTM1 & & & & \\
Present & $16(47.1)$ & $25(64.1)$ & 1 & \\
Null & $18(52.9)$ & $14(35.9)$ & $2(0.79-5.14)$ & 0.145 \\
GSTT1 & & & & \\
Present & $24(70.6)$ & $36(92.3)$ & 1 & \\
Null & $10(29.4)$ & $3(7.7)$ & $5(1.25-20.1)$ & 0.023 \\
\hline
\end{tabular}

control (40.9\%); however, it was not associated with an increased risk to develop CML (OR 95\% CI, 1.4, 0.782.48; $\mathrm{p}=0.271$ ) (Table 1). Furthermore, the estimation of CML risk, according to the gender of participants showed similar trends in males (OR 95\% CI, 2, 0.795.14; $\mathrm{p}=0.145$ ) (Table 3) as well as in females (OR 95\% CI, 1.01, 0.52-2.3; $\mathrm{p}=0.823$ ) (Table 4). Similar findings were observed in India with (OR 95\% CI, 1.32, 0.73-2.40; $\mathrm{p}=0.4295$ ) (Bhat et al. 2012). Özten et al. 2012, also found no association between GSTM1 null genotype and CML (OR 95\% CI, 1.11; 0.69-1.80; $\mathrm{p}=0.714$ ). A meta-analysis realized with a large number of participants confirmed these results (Zintzaras 2009). The analyze of these different results shows that GSTM1 null genotype seems not to be associated with the development of CML.

Overall, the GSTT1 null genotype was not found to be associated with the development of CML when males and females were pooled together (OR 95\% CI, 1.97; $0.82-4.71 ; \mathrm{p}=0.13$ ) (Table 1). A study carried in Japan, also failed to find any association between GSTT1 null genotype and CML (Hishida et al. 2005). Surprisingly, in considering participants according to gender, we have found a significant association between GSTT1 null genotype and CML in males (OR 95\% CI, 5; 1.25-20.1; p = 0.023 ) (Table 3) but not in females (OR 95\% CI, 0.9; 0.283.06; $\mathrm{p}=0.896$ ) (Table 4). This finding might be explained by differences in xenobiotics exposure between males and females (e.g. Smoke, pesticides) or other genetic/non

Table 4 Effect of GSTM1 and GSTT1 genotypes on the development of CML in females

\begin{tabular}{lllll}
\hline GST polymorphism & $\begin{array}{l}\text { Patients } \\
\mathbf{N}(\%)\end{array}$ & $\begin{array}{l}\text { Control } \\
\mathbf{N}(\%)\end{array}$ & $\begin{array}{l}\text { OR } \\
\mathbf{9 5 \%} \mathrm{Cl}\end{array}$ & P value \\
\hline GSTM1 & & & & \\
Present & $31(53.4)$ & $30(55.6)$ & 1 & \\
Null & $27(46.6)$ & $24(44.4)$ & $1.01(0.52-2.3)$ & 0.823 \\
GSTT1 & & & & \\
Present & $52(89.7)$ & $48(88.9)$ & 1 & \\
Null & $6(10.6)$ & $6(11.1)$ & $0.9(0.28-3.06)$ & 0.896 \\
\hline
\end{tabular}


genetic factors specific to the host. Otherwise, a Turkish study reported an association between GSTT1 null genotype and CML (OR 95\% CI, 2.82; 1.58-5.05; p < 0.001) (Taspinar et al. 2008). Another study done in India, also found that GSTT1 null genotype was associated with the development of CML (OR 95\% CI, 2.67; 1.03-7.01) (Bajpai et al. 2007).

The combined GSTM1 present/GSTT1 null genotype was found to have a limited effect against the development of CML when compared to GSTM1 present/ GSTT1 present genotype (OR 95\% CI, 0.3, 0.08-0.99; $\mathrm{p}=$ 0.049). Anyway, this finding shows a marginal interaction, between GSTM1 and GSTT1 genes. (Zintzaras 2009) has reported a significant association between GSTM1 present/GSTT1 null genotype and CML. Elsewhere, we found that the GSTM1 null/GSTT1 null genotype was not associated with the development of CML when compared to GSTM1 present/GSTT1 present genotype (OR 95\% CI, 0.61, 0.17-2.13; $\mathrm{p}=0.434)$. In contrast, other authors have found that GSTM1 null/GSTT1 null genotype exposed significantly subjects to develop CML when compared to GSTM1 present/GSTT1 present genotype (Bhat et al. 2012; Özten et al. 2012), some authors, reported that subjects with GSTM1 present/GSTT1 null genotype were 2.5 times more likely to develop CML when compared to GSTM1 null/GSTT1 present genotype (Özten et al. 2012). The results from these authors show a possible interaction between GSTM1 and GSTT1.

\section{Conclusion}

To the best our knowledge, this is the first study on a Moroccan population, assessing the risk of GSTM1 and GSTT1 null genotype carriers in the development of CML. This study has allowed to determine the frequency of GSTM1 and GSTT1 polymorphism in a sample of our population. In addition, we have noted that the GSTT1 null genotype is associated with the development of CML in males but not in females.

\section{Competing interests}

The authors declare that they have no competing interests.

\section{Authors' contributions}

KY designed and performed the research, analyzed and interpreted the data, created the tables, and wrote the paper; DH designed the research, participated in sample genotyping; $\mathrm{QM}$ and $\mathrm{AQ}$ designed the research, participated in sample collection; BS and NS, participated in a critical revision of the article. All authors approved the final version submitted for publication.

\section{Acknowledgments}

Financial support for this study was obtained from the Hassan II Academy of Science and Technology.

\section{Author details}

${ }^{1}$ Genetics and Molecular Pathology Laboratory, Medical School of Casablanca, 19 Rue Tarik Ibnou Ziad, Casablanca BP 9154, Morocco. ${ }^{2}$ Department of Onco-Hematology, Ibn Rochd University Hospital, Casablanca, Morocco.
Received: 10 December 2014 Accepted: 2 April 2015

Published online: 01 May 2015

\section{References}

Baccarani M, Cortes J, Pane F, Niederwieser D, Saglio G, Apperley J, Cervantes F, Deininger M, Gratwohl A, Guilhot F, Hochhaus A, Horowitz M, Hughes T, Kantarjian H, Larson R, Radich J, Simonsson B, Silver RT, Goldman J, Hehlmann R. Chronic myeloid leukemia: an update of concepts and management recommendations of European LeukemiaNet. J Clin Oncol [Internet]. 2009 [cited 2014 Mar 29];27:6041-51. Available from: http://www.ncbi.nlm.nih.gov/pubmed/19884523

Bajpai P, Tripathi AK, Agrawal D. Increased frequencies of glutathione-S-transferase (GSTM1 and GSTT1) null genotypes in Indian patients with chronic myeloid leukemia. Leukemia research [Internet]. 2007 [cited 2013 Nov 25];31:1359-63. Available from: http://www.ncbi.nlm.nih.gov/pubmed/17420047

Belitsky GA, Yakubovskaya MG (2008) Genetic polymorphism and variability of chemical carcinogenesis. Biochemistry Biokhimiia [Internet] 73:543-54, Available from: http://www.ncbi.nlm.nih.gov/pubmed/18605979

Bhat G, Bhat A, Wani A, Sadiq N, Jeelani S, Kaur R, Masood A, Ganai B (2012) Polymorphic variation in glutathione-S-transferase genes and risk of chronic myeloid leukaemia in the Kashmiri population. Asian Pacific journal of cancer prevention: APJCP [Internet] 13:69-73, Available from: http://www.ncbi.nlm.nih.gov/pubmed/22502716

Deininger MWN, Goldman JM, Melo JV (2000) The molecular biology of chronic myeloid leukemia. Blood 96:3343-56

Dong G, Tian Y, Chen S, Xu X, Zheng J, Li T (2013) Glutathione S-transferase T1 null genotype is associated with oral cancer susceptibility in Asian populations. Tumor Biol 34:1753-7

Duggan C, Ballard-Barbash R, Baumgartner RN, Baumgartner KB, Bernstein L, McTiernan A (2013) Associations between null mutations in GSTT1 and GSTM1, the GSTP1 lle (105)Val polymorphism, and mortality in breast cancer survivors. Springerplus 2:450, doi: 10.1186/2193-1801-2-450

Dunna NR, Vure S, Sailaja K, Surekha D, Raghunadharao D, Rajappa S, Vishnupriya S (2013) Deletion of GSTM1 and T1 genes as a risk factor for development of acute leukemia. Asian Pacific journal of cancer prevention: APJCP [Internet] 14:2221-4, Available from: http://www.ncbi.nlm.nih.gov/pubmed/23725116

Fang J, Wang S, Zhang S, Su S, Song Z, Deng Y, et al. Association of the glutathione s-transferase $\mathrm{m} 1, \mathrm{t} 1$ polymorphisms with cancer: evidence from a meta-analysis. PloS One [Internet]. 2013 [cited 2013 Nov 21];8:e78707. Available from: http://www.pubmedcentral.nih.gov/articlerender.fcgi?artid= 3826727\&tool=pmcentrez\&rendertype $=$ abstract

Garte S, Gaspari L, Alexandrie A, Ambrosone C, Autrup H, Autrup JL, Baranova H, Bathum L, Benhamou S, Boffetta P, Bouchardy C, Breskvar K, Brockmoller J, Cascorbi I, Clapper ML, Coutelle C, Daly A, Dell'Omo M, Dolzan V, Dresler CM, Fryer A, Haugen A, Hein DW, Hildesheim A, Hirvonen A, Hsieh LL, Ingelman-Sundberg M, Kalina I, Kang D, Kihara M et al (2001) Metabolic Gene Polymorphism Frequencies in Control Populations Metabolic Gene Polymorphism Frequencies in Control Populations. Cancer Epidemiol Biomarkers Prev 10:1239-48

Gervasini G, García-Martín E, Ladero JM, Pizarro R, Sastre J, Martínez C, García M, DiazRubio M, Agúndez JA et al (2007) Genetic variability in CYP3A4 and CYP3A5 in primary liver, gastric and colorectal cancer patients. BMC Cancer [Internet]. [cited 2013 Dec 12];7:1-7. Available from: http://www.pubmedcentral.nih.gov/ articlerender.fcgi?artid=1931602\&tool=pmcentrez\&rendertype=abstract

Hallier E, Langhof T, Dannappel D, Leutbecher M, Schröder K, Goergens HW, Müller A, Bolt HM (1993) Polymorphism of glutathione conjugation of methyl bromide, ethylene oxide and dichloromethane in human blood: influence on the induction of sister chromatid exchanges (SCE) in lymphocytes. Archives of toxicology [Internet] 67:173-8, Available from: http://www.ncbi.nlm.nih.gov/pubmed/8494496

Hayes JD, Pulford DJ (1995) The glutathione S-transferase supergene family: regulation of GST and the contribution of the isoenzymes to cancer chemoprotection and drug resistance. Critical Reviews in Biochemistry and Molecular Biology [Internet] 30:445-600, Available from: http://www.ncbi.nlm.nih.gov/pubmed/8770536

Hishida A, Terakura S, Emi N, Yamamoto K, Murata M, Nishio K, Sekido Y, Niwa T, Hamajima N, Naoe T. GSTT1 and GSTM1 deletions, NQO1 C609T polymorphism and risk of chronic myelogenous leukemia in Japanese. Asian Pacific journal of cancer prevention: APJCP [Internet]. 2005;6:251-5. Available from: http://www.ncbi.nlm.nih.gov/pubmed/16235982 
Kawajiri K, Nakachi K, Imai K, Watanabe J, Hayashi S. The CYP1A1 gene and cancer susceptibility. Critical reviews in oncology/hematology [Internet]. 1993;14:77-87. Available from: http://www.ncbi.nlm.nih.gov/pubmed/8103989

Ma W, Zhuang L, Han B, Tang B (2013) Association between glutathione S-transferase T1 null genotype and gastric cancer risk : a meta-analysis of 48 studies. PLoS One 8:60833

Mannervik B, Awasthi YC, Board PG, Hayes JD, Di Llo C, Ketterer B, Listowsky I, Morgenstern R, Muramatsu M, Pearson WR (1992) Nomenclature for human glutathione transferases. Biochem J 282:305-6

Miller S, Dykes D, Polesky H (1988) A simple salting out procedure for extracting DNA from human nucleated cells. Nucleic Acids Res 16:1215

Mossallam Gl, Abdel Hamid TM, Samra MA. Glutathione S-transferase GSTM1 and GSTT1 polymorphisms in adult acute myeloid leukemia; its impact on toxicity and response to chemotherapy. J Egypt Natl Canc Inst [Internet]. 2006;18:264-73. Available from: http://www.ncbi.nlm.nih.gov/pubmed/17671537

Özten N, Sunguroğ A, Bosland M (2012) Variations in glutathione-S- transferase genes influence risk of chronic myeloid leukemia. Hematol Oncol 30:150-5

Pearson WR, Vorachek WR, Xu SJ, Berger R, Hart I, Vannais D, Patterson D (1993) Identification of class-mu glutathione transferase genes GSTM1GSTM5 on human chromosome 1p13. Am J Human Genetics [Internet] 53:220-33, Available from: http://www.pubmedcentral.nih.gov/ articlerender.fcgi?artid=1682241\&tool=pmcentrez\&rendertype=abstract

Salagovic J, Kalina I, Dudas M (2000) Genetic polymorphism of enzymes metabolizing xenobiotics as a factor in susceptibility to tumor development. Bratislavské lekárske listy [Internet] 101:512-21, http://www.ncbi.nlm.nih.gov/ pubmed/11187056

Sharma T, Jain S, Verma A, Sharma N, Gupta S, Arora VK, Dev Banerjee B (2013) Gene environment interaction in urinary bladder cancer with special reference to organochlorine pesticide: a case control study. Cancer Biomark 13:243-51

Siraj AK, Ibrahim M, Al-Rasheed M, Abubaker J, Bu R, Siddiqui SU, et al. Polymorphisms of selected xenobiotic genes contribute to the development of papillary thyroid cancer susceptibility in Middle Eastern population. BMC medical genetics [Internet] 2008 [cited 2013 Nov 22];9:1-9. Available from: http://www.pubmedcentral.nih.gov/articlerender.fcgi?artid $=2492854 \&$ tool=pmcentrez\&rendertype=abstract

Taioli E (1999) International collaborative study on genetic susceptibility to environmental carcinogens. Cancer Epidemiol Biomarkers Prev 8:727-8

Taningher M, Malacarne D, Izzotti A, Ugolini D, Parodi S. Drug metabolism polymorphisms as modulators of cancer susceptibility. Mutat Res [Internet]. 1999;436:227-61. Available from: http://www.ncbi.nlm.nih.gov/pubmed/10354524

Taspinar M, Aydos SE, Comez O, Elhan AH, Karabulut HG, Sunguroglu A. CYP1A1, GST gene polymorphisms and risk of chronic myeloid leukemia. Swiss Med Wkly [Internet]. 2008;138:12-7. Available from: http://www.ncbi.nlm.nih.gov/ pubmed/18224491

Van der Logt EM, Bergevoet SM, Roelofs HMJ, Van Hooijdonk Z, Te Morsche RHM, Wobbes T, de Kok JB, Nagengast FM, Peters WH. Genetic polymorphisms in UDP-glucuronosyltransferases and glutathione S-transferases and colorectal cancer risk. Carcinogenesis [Internet]. 2004 [cited 2013 Dec 6];25:2407-15. Available from: http://www.ncbi.nlm.nih.gov/ pubmed/15319294

Voso MT, D'Alo' F, Putzulu R, Mele L, Scardocci A, Chiusolo P, Latagliata R, Lo-Coco F, Rutella S, Pagano L, Hohaus S, Leone G. Negative prognostic value of glutathione S-transferase (GSTM1 and GSTT1) deletions in adult acute myeloid leukemia. Blood [Internet]. 2002 [cited 2013 Nov 26];100:2703-7. Available from: http://www.ncbi.nlm.nih.gov/pubmed/12351375

Webb G, Vaska V, Coggan M, Board P. Chromosomal localization of the gene for the human theta class glutathione transferase (GSTT1). Genomics [Internet]. 1996;33:121-3. Available from: http://www.ncbi.nlm.nih.gov/pubmed/8617495

Zintzaras E (2009) Glutathione S-transferase M1 and T1 genes and susceptibility to chronic myeloid leukemia : a meta- analysis. Genet Test Mol Biomarkers $13: 791-7$

\section{Submit your manuscript to a SpringerOpen ${ }^{\circ}$ journal and benefit from:}

- Convenient online submission

Rigorous peer review

- Immediate publication on acceptance

- Open access: articles freely available online

- High visibility within the field

- Retaining the copyright to your article

Submit your next manuscript at $>$ springeropen.com 